\title{
High-rise architecture in Ufa, Russia, based on crystallography canons
}

\author{
Ildar Narimanovich Sabitov ${ }^{1 *}$, Dilara Radikovna Kudasheva ${ }^{1}$, Denis Yaroslavovich \\ Vdovin $^{1}$ \\ ${ }^{1}$ Ufa State Petroleum Technological University, Ufa, 450062, Kosmonavtov st., 1, Russia
}

\begin{abstract}
The article considers fundamental steps of high-rise architecture forming stylistic tendencies, based on C. Willis and M. A. Korotich's studies. Crystallographic shaping as a direction is assigned on basis of classification by M. A. Korotich's. This direction is particularly examined and the main high-rise architecture forming aspects on basis of natural polycrystals forming principles are assigned. The article describes crystal forms transformation into an architectural composition, analyzes constructive systems within the framework of CTBUH (Council on Tall Buildings and Urban Habitat) classification, and picks out one of its types as the most optimal for using in buildings-crystals. The last stage of our research is the theoretical principles approbation into an experimental project of high-rise building in Ufa with the description of its contextual dislocation aspects.
\end{abstract}

\section{Introduction}

Today, equally with such unquestionable factors as: economical susceptibility, high cost of lots within the city boundaries, approach to raise image constituent and attraction for tourists, growth of the city status and economic efficiency of projects, one of the most basic factor of the high-rise buildings forming is an object's spatial composition, its appearance and design. According to that, not for a long time there has been created a big quantity of stylistic methods and tendencies of the high-rise architecture cover design, using mathematical functions and formulas, contextual specifics, method of the form following the function, metaphorical transfer of the natural specifics to the architectural form, etc [1, 2, 3, 4]. However, what "high-rise building" is? According to CTBUH classification (Council on Tall Buildings and Urban Habitat) [5] there are three wraparound groups of high-rise buildings: Tall to $300 \mathrm{~m}$, Supertall from 300 to $600 \mathrm{~m}$, Megatall (from $600 \mathrm{~m}$ and higher). The high-rise or Tall building - is rather subjective conception, regarding to the context, proportions and technological fitting out. In New York the 20-storey building would be difficult to name as a high-rise, but, for example, in Prague it would be obviously higher than the main mass of buildings. Also, there exist buildings with an expressed proportional ratio of the base sides to the vertical axis. A building can reach $100 \mathrm{~m}$ along

\footnotetext{
*Corresponding author: ufasabitov@gmail.com
} 
the vertical, and have ribs of the base for $50 \mathrm{~m}$. In such buildings there also can be used technological systems and elements, inherent in high-rise. If an object gets into one of these categories, it could be high-rise. Objectively, any object could be the high-rise, if its top level gets $50 \mathrm{~m}$ from the ground. There is a classification of constructive systems:

- A steel framework - vertical and horizontal constructive elements composed of steel elements. If a ceiling construction is a concrete slab, laid on steel beams, then a system would relate to the steel framework.

- A concrete framework - vertical and horizontal elements consist of concrete.

- A mixed framework - using two full systems in one buildings - steel and concrete frameworks with an interchange.

- A composite framework - combination of steel and concrete elements in one constructive scheme, for example, composite columns, steel columns with reinforced concrete and a core, etc.

Today there exist also «wooden skyscrapers» - high-rise buildings, in which the main constructive element is a wooden beam and steel fastening elements.

Carol Willis describes minimalistic and the most rational periodization of the high-rise architecture development: the first period (before 1940), including «historicism» architecture, the Chicago school of high-rise architecture and modern [6]. By the second period, she ascribes modernism and post-modern, that included most of all modern developing form-building tendencies. Nowadays the last landmark of architectural styles development is post-metabolism or, in other words, «authoring architecture». This tendency is hard to ascribe to the one period or style, because it includes complex relationships of a multitude of stylistic tendencies, national cultural specifics, authoring solutions, etc. M. A. Korotich described compositional specifics of high-rise architecture development [7, 8]. He detected two basical periods: the initial one, during which have formed the main prototypes of the skyscrapers forms, and the modern one, within the framework of which Korotich ascribes three basic compositional form-shaping tendencies of high-rise architecture. The first tendency includes a period from the end of 20 century to 1980-1990-s. Its characteristics are:

- Decorative elaboration of elemental prismatic generalized forms of high-rise buildings.

- Division or shaping using vertical bay windows, pylons.

- «Telescopic» buildings.

- A wide use of historical architectural styles elements.

The second tendency originates in the second half of the 20 century and is actively used by architects nowadays. It originates from Soviet avant-garde, conceptual projects by I. Leonidov, V. Krinsky and N. Ladovsky (fig.1).

Its characteristics are:

- Abundance of plane-face truncation of the initial prismatic forms with different transversal sections.

- Combination of separate objects into complex compound compositions.

- Full or primary use of glass as a material of the skyscrapers cover.

The third tendency begins its development from the second half of 20 century (1970-s)

and is actual till nowadays. Its characteristics are:

- Development of the list of high-rise architecture initial forms.

- Use of different forms of form-development (twist, bend, etc.).

- A wide use of the high-rise architecture complexes.

- Use of decoratively-plastic solutions of national architectural motives.

- Combination of structurally heterogeneous, but compositionally interchangeable elements of composition. 


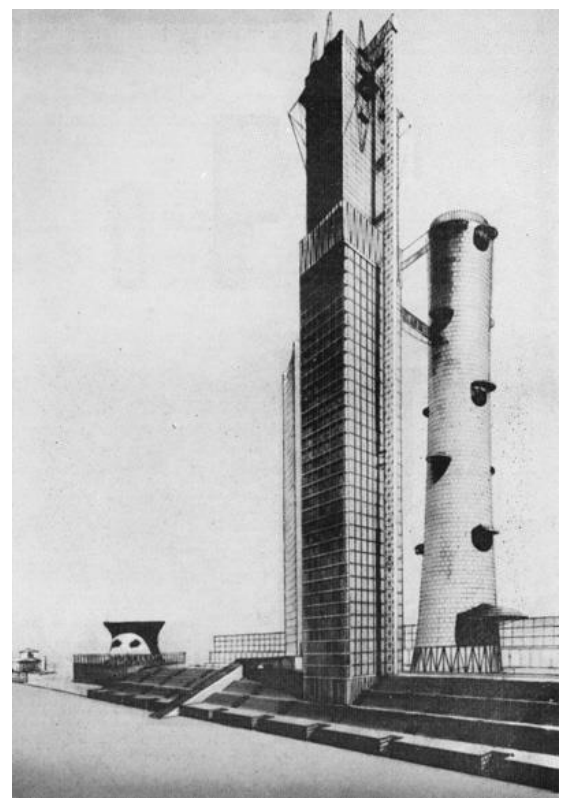

Fig.1 Project of the new building of National commissariat of heavy industry,1934

The architectural filling of Ufa is a complex stratified structure that has passed a style mixing, such as: classicism, Stalinist architecture, Soviet modernism, brick eclecticism, the post-modernism. Nowadays in the city there prevail a quoting of the West European architecture - modernistic methods and rethinking of Soviet modernism, less commonly using neoclassical methods. There are also used: constructivism, adapted to modern materials, «facadizm», characterized by the illusion of integrity, sharp collision of styles classical facades combined with glass up-and-over walls, steel and concrete constructions [9]. Just now, during the rising of architectural aesthetics level, when the building culture of the region endures its growth and new technologies implementation, and the normative legal base of the Russian Federation at last has filled with the document of high-rise architecture erection rules (Joint venture 267.1325800.2016 «High-rise buildings and complexes. Rules of planning»), it is necessary to form a flexible language for all future buildings, giving a development vector in this direction.

\section{Materials and methods}

Crystallography is nonrandom chosen as a base for an architectural image creating - under the city there is an advanced system of gypsum and other mineral-based materials generation. The main type of the city industry - oil production and refining, and geological explorations are a compound part of this process [10]. Crystallography is known as a part and parcel of geology. Also, Ufa is associated with water, two rivers that go about the city in the east and west and one of the water conditions - hard - is a crystal. Crystal bodies, consisted of some grown together single crystals, «polycrystals» are the architectural composition prototype. Single crystals, growing in the structure of these formations begin to compete with each other, trying to fix their developing vector, thus, mass of this shoot grows, that influences on its dimensions. Other single crystals that didn't make progress have to change their vector of development for a growth continuation. At the expense of this anisochronous development, every polycrystal formation would get a unique appearance. Despite the fact that most of these formations have an evident vector of 
growth, or «development axis», not all polycrystals develop the same way, there also exist formations, where a quantity of single crystals are developed rather equally, that makes the formation silhouette less contrast from the spatial composition point of view [11]. That property of crystals, in view of their geometrical foundation and naturalness, can be adapted to architectural forming principles, taking account of the spatial composition of architectural objects. Then there would be given the main points of natural crystal transforming into an architectural spatial composition algorithm:

1. Correction of the crystal's «growth axis» deviation to acceptable altitudes. It is important to take into consideration that for hardness of the expressed growth axis would be given by the constructive stiffening core, it is necessary to hold perpendicularly to the basement (fig. 2).

2. Forming of the object's stylobate fragment. Optimization and generalization of the small single crystals form and their merging into the unified mass. Small single crystals develop and grow chaotically in a polycrystal structure, based on the principle that is true for the all polycrystals. It is necessary to run processes of generalization and optimization to get a tectonically correct spatial composition. (fig. 3).

3. Forming a spatial composition from the skyscraper's dominant part. A natural single crystal, more developed in a polycrystal structure, is equal to a high dominant of the complex - a skyscraper. A natural form of an ideal single crystal is a prismatic polyhedral quantum with different degree and angle of the top borders truncation that could be conditionally compared to a pencil. This form is often complicated by the small single crystals that have ingrown. For transforming into the tectonic spatial composition it is necessary to get that form through the generalization, primitivization, decompozition processes (fig. 4).

4. The parts conjugation into a united structure. For the united complex construction it is necessary to form a rhythmical structure, that, on the one hand, should quote some natural crystal formations properties, and on the other hand - be an architectural building with rational tectonic structure and spatial composition, that is peculiar to it. It is possible by finding a rhythmical language of separate blocks linking into a united spatial composition (fig. 5).

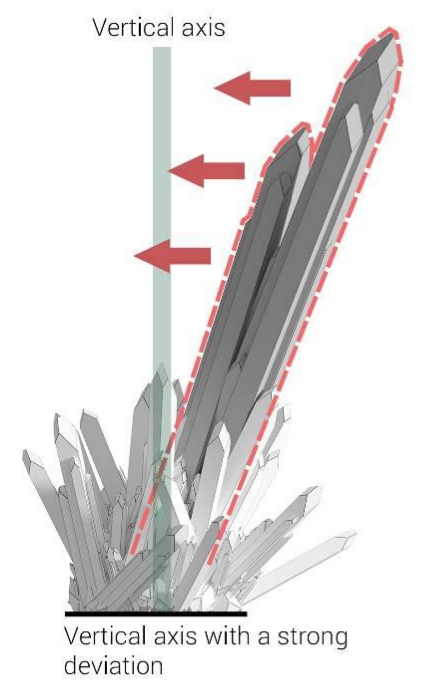

Fig. 2 Scheme of the crystal's «vertical axis» deviation.

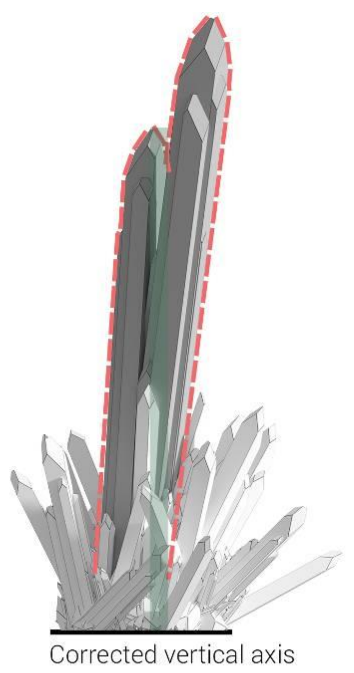


1) Identification of outline of crystal mass and amplification vectors

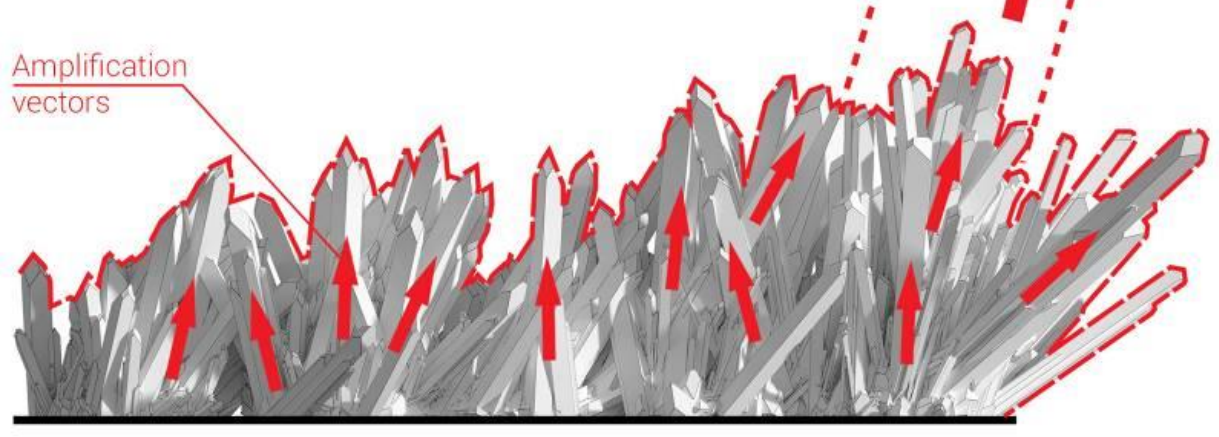

2) Outline optimization

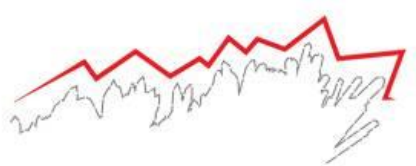

3) Identification of "intensity lines"

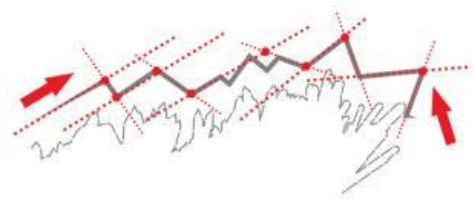

4) Formation of final outline



5) Final outline with possible extension of main amplification

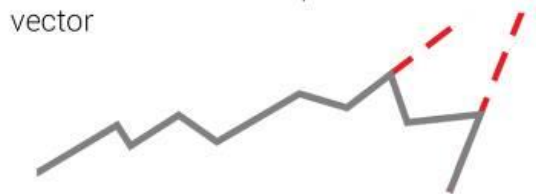

Fig. 3 The polycrystal mass generelization scheme.

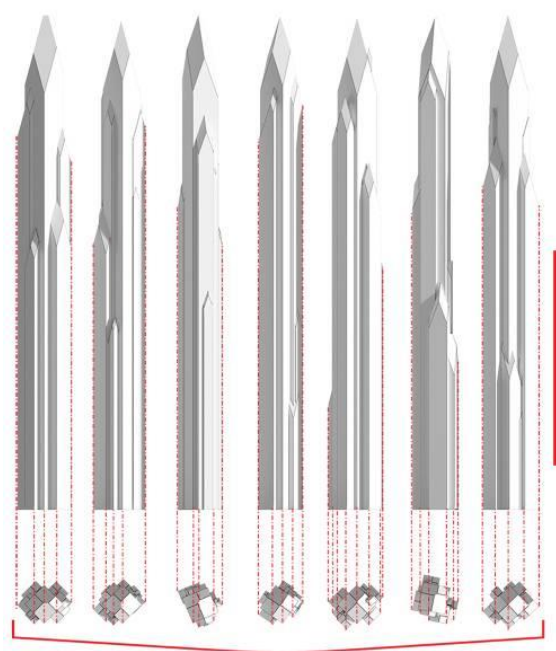

complex geometric form

negative impact on aerodynamic characteristics of future form
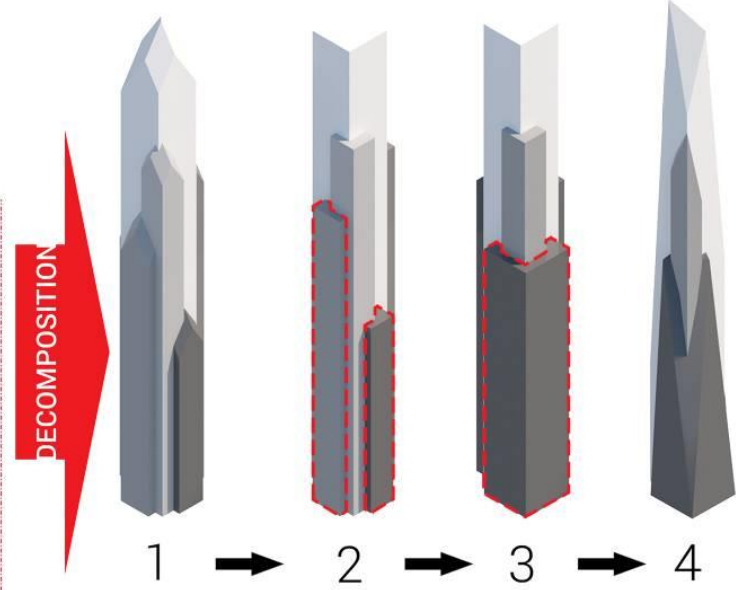

1 - Modules isolated
2 - Form degradation

2- Form degradation
3 - Modules merged

4 - Main crystal structure reformed

Fig. 4 The spatial dominant form composition. 

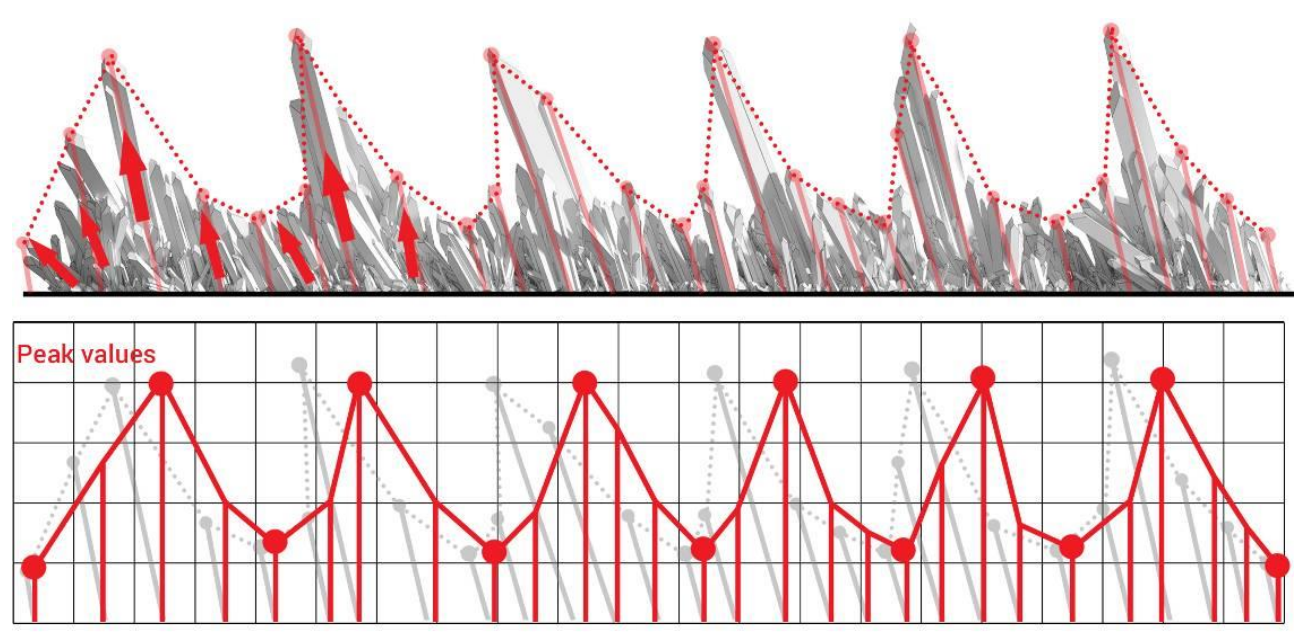

Fig. 5 The rhytmical structure analysis.

At this stage of development, this technology of erection is not a lack of shortages buildings are limited enough in proportions and height [12]. During the long time, there has been used a standard inner framework with a core - the ladder and elevator block in which also were all engineer systems. Today is widely used a type of external framework - in this system the core is also situated inside the building (rarely displaced from the center, more rarely - gets outside), and the main supporting member are taken out to the facade, underlining structural properties and tectonics of the building, releasing big squares inside $[43,14,15]$. Such solution is recommended to use in crystal form transmission, to get the most expressed and tectonic appearance of a spatial composition.
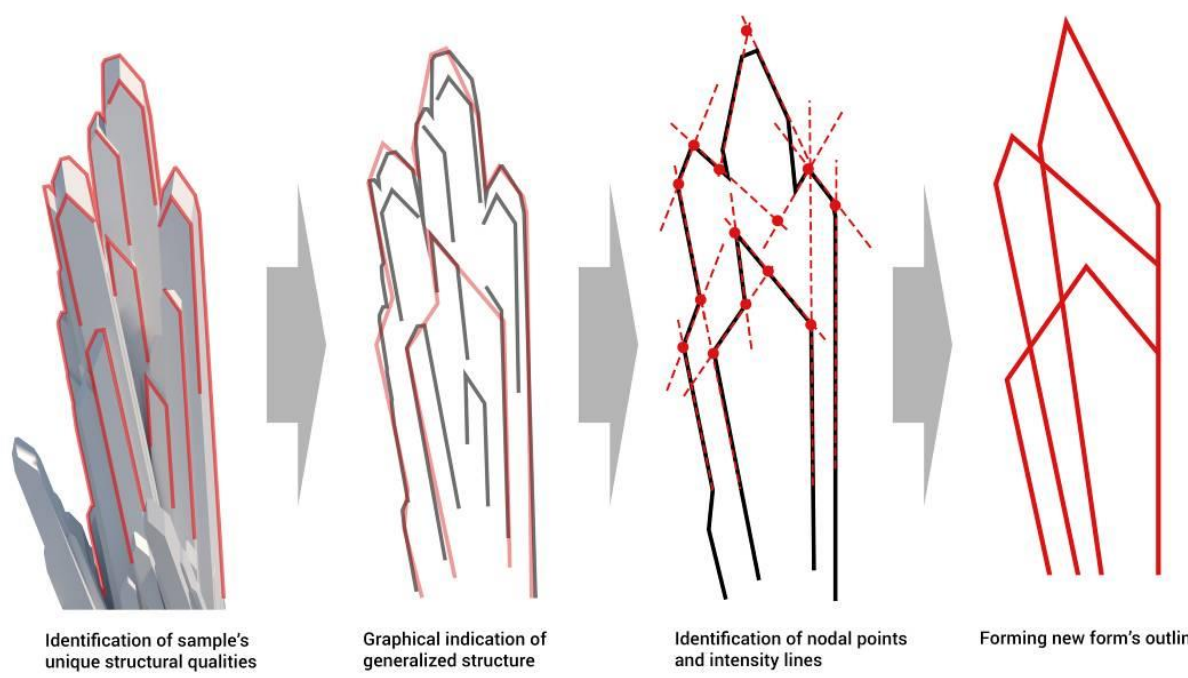

Identification of nodal points and intensity lines

Forming new form's outline

Fig. 6 The compositional structure of the crystal form exposure.

Crystal forms have such a high visual expression degree due to its hardly ribbed structure - arranging borders at different angles to the light, every crystal has its own individual appearance and constructive system, based on hard conjugation of its form ribs. Adapting a natural crystal form to the architectural spatial composition it is necessary to 
understand that the form needs alignment and rethinking at the stage of early sketches for the most optimal inner spaces distribution and adequate constructive scheme behavior. At the same time it is necessary to represent an individual image and a visual effect from an initial crystal prototype and study axonometric projection of the form to reveal force points of ribs coupling and the main compositional efforts in a crystal silhouette (fig. 6). For the research approbation there has been taken a regional city of Ufa - the capital of the Bashkortostan Republic.

\section{Results}

The Ufa city planning structure is a linear city, spreading from the south to the north and bordered by the Belaya River from the south to the west and the Ufa River from the east. A rapidly growing level of the city urbanization, actively projects under construction, business-centers and public buildings burden the transport infrastructure. As a result, there is a multitude of 10-point traffics at the main city roads. All this is aggravated by the main infrastructure problems - weak transport links between the city districts, distant from each other $[16,17,18,19,20]$. There is a way to enhance this links by bringing an overhead monorail, new in principle transport system.

The overhead monorail advantages are: relatively rapid velocity of travel - up to 50 $\mathrm{km} / \mathrm{h}$, a car capacity - up to 65 people (20 sitting places), 250 people is a maximum for 4 cars - rolling stock capacity. Therefore, it is possible at rush-hours to transport up to 5000 people per hour in one direction with intervals for 3 minutes. This system doesn't have a bad effect on the environment, is virtually noiseless, the permissible distance from dwellings windows is 15 meters.

The first step of this transport system introduction into the Ufa city is to strengthen the west and east city parts transport links by laying a number of new streets, which are perpendicular to the main transport arteries (Oktyabrya Prospect, Salavata Yulaeva Prospect). Strengthening of these links would serve as a basis of the next step - the Ufa overhead monorail's main branch (fig. 7). The central branch would stretch out along one of the main city roads - Salavata Yulaeva Prospect. The overhead monorail stops must be located in points of intersections with streets, linking east and west parts of the city, such as: 50 let SSSR street, Sagit Agisha - Revolutsionnaya street, Ayskaya - Bakalinskaya, Zaki Validi - Sochinskaya. The overhead monorail first stage development will stretch along the largest city districts and link the most remote from each other territories - Ufa international airport in the south and the industrial estate «Ufaneftehim» in the north. The second step permits to link a city base with new perspective districts, developing from the former suburban settlements. Creating intercepting parkings at the terminus would shorten the transport stream that enters the city.

The overhead monorail stations should be linked with bus-stops by pedestrian crossings (the fixed-run bus taxi, the state transport system), that will directly transport to the destination. These links are necessary for indissoluble and non-suture transporting city system creation. Arrangement of the stations a little way from the carriage-way, at the favourable places for little public spaces organization and parting passenger traffics would be the most optimal method.

The overhead monorail is suggested to make by means of the H-Bahn technology («hanging railway»), which is the double-track overhead system on rod posts. The advantages of this solution are: an economical profit (this type is easier, faster, cheaper in building); an aesthetics (convinient rod posts construction); safety; simplicity in use (the construction is protected from weather conditions influence, sabotage and vandalism). 


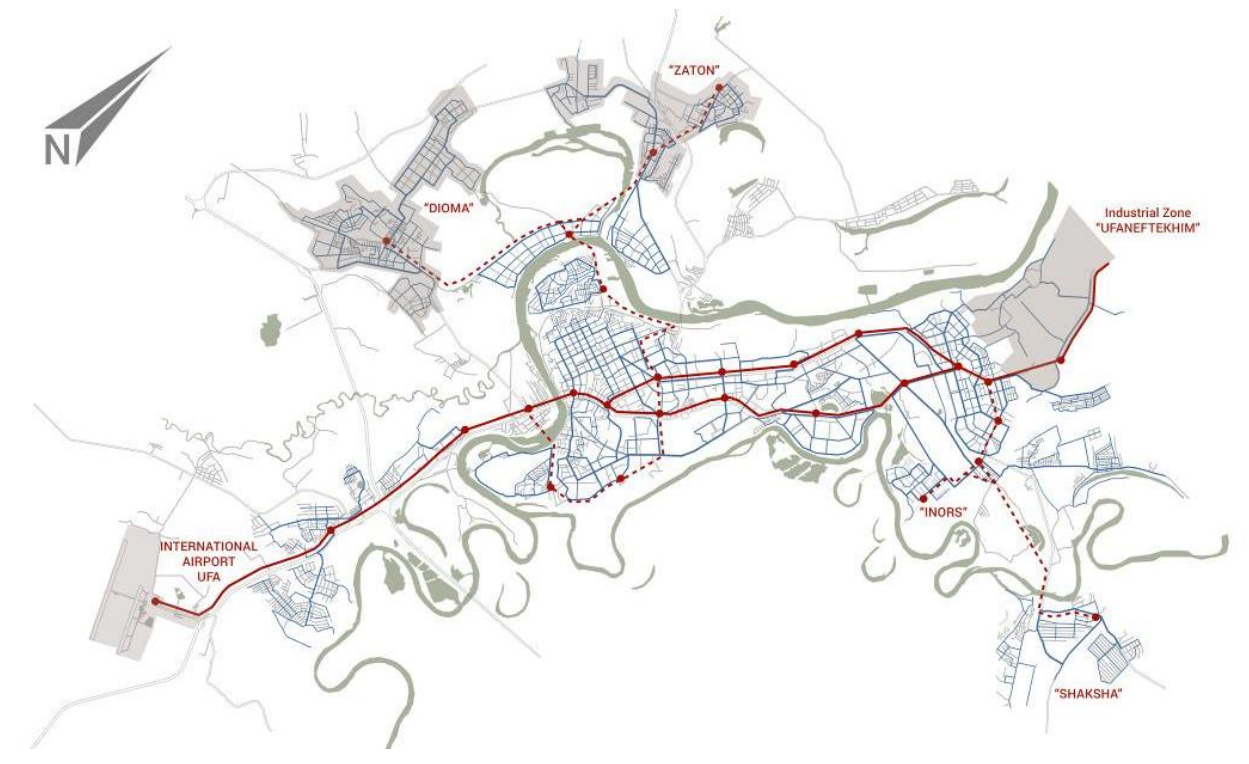

Fig. 7 The overhead monorail arrangement scheme.

With the correct interaction of different types of public transport, such as a monorail, a bus, a trolleybus, a tram, would be created an advanced transport network that links all city districts. The suggested transport structure would minimize the passengers provisional cost for transportation within the frameworks of the city, shorten the number of traffics; optimize the routes for dwellers and city guests. The main transport road territory Salavata Yulaeva Prospect is not ennobled because of it's strictly transit function. In the perspective, this city artery would become the main city axis, its gate, because the main entry in the city is the beginning of that road. Erection of the suggested experimental project would develop territories, contiguous to the prospect that would be a positive point of a visual perception of the city. A beautifying level growth would uplift the district environment quality; reduce the exhaust gases influence upon the citizens and the administrative buildings employees. At a later date, perspective plans of this aspect development are linked with the creation of the green belt along Salavata Yulaeva Prospect that would help to link this district with the main recreational framework of Ufa (fig. 9)

\section{Conclusion}

On the basis of the aforesaid, it is possible to ascertain that the form-building aspect of the high-rise building is one of the most important factors of its future development, because, taking into consideration a level of the building science and technologies all in all, today every architectural idea can practically realize. That is why it is important to pay attention to the form-building and spatial modelling, as well as to the economical or technological factors. Crystallography is an inexhaustible source of impression for architectural forming, because it contains a great resource of canons and rules, that, with due notice and examination would accommodate to the spatial composition, at that, there is created an individual object appearance that possesses high aesthetic properties, because a crystal is a natural formation and the nature is the best artist and engineer. That compositional development direction in high-rise architecture and skyscrapers is one of those vectors that would be actively develop in future and change the city image, we are living today. 

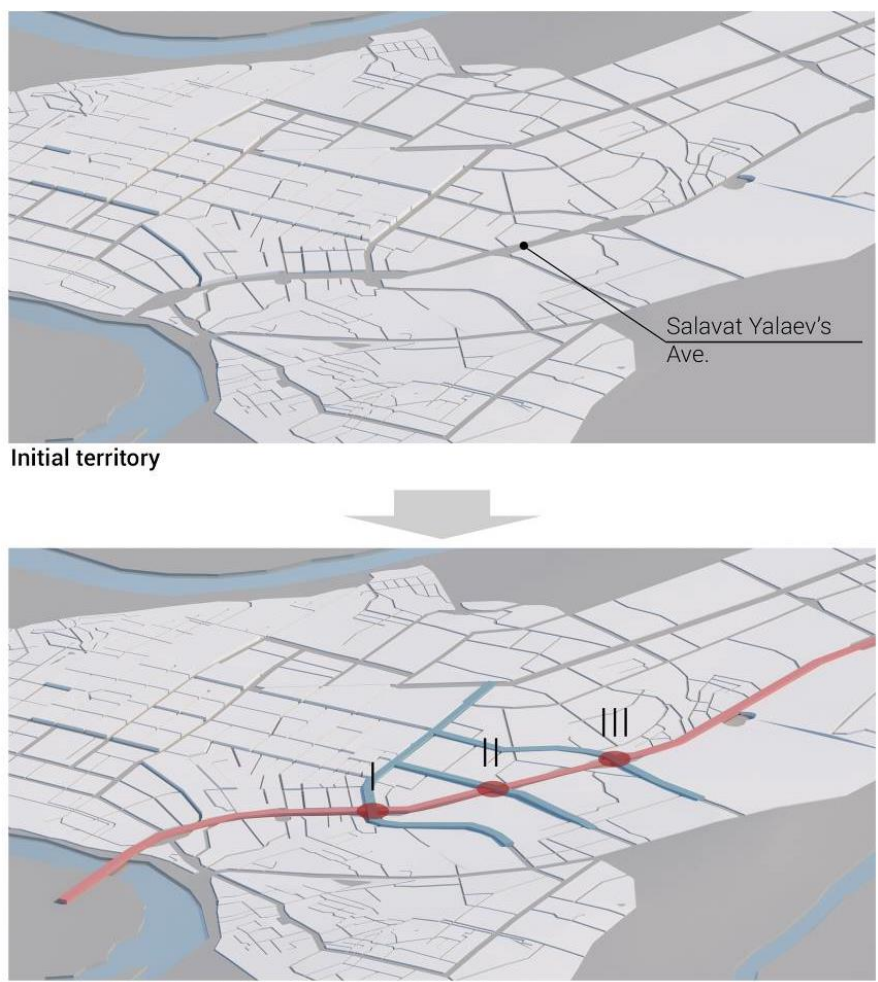

Identification of main transportation intersections

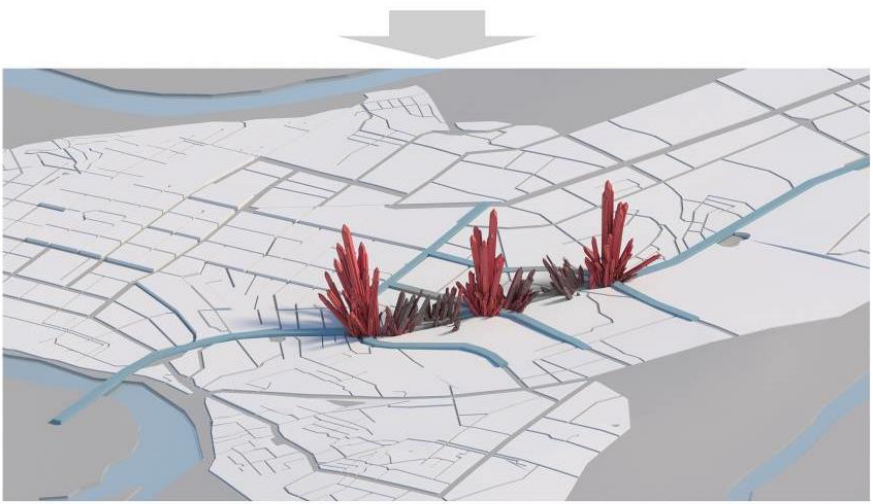

Growth of crystal forms on nodal points. "Dominant - submissive" relationships

Fig. 8 The image forming in the context.

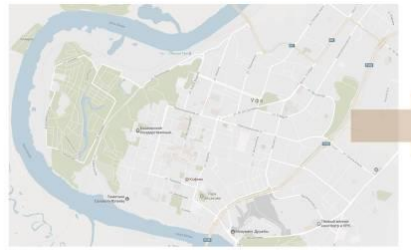

Initial territory

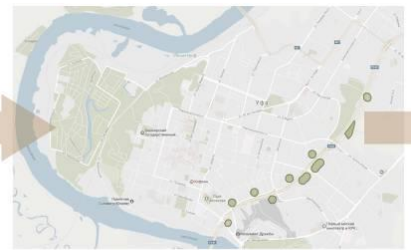

"Green Isles" formed

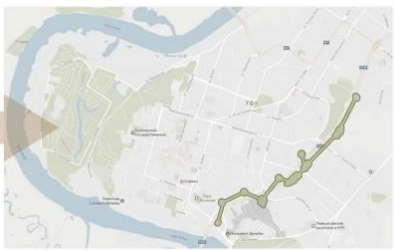

Recreational frame formed

Fig. 9 The recreational framework development scheme. 


\section{References}

1. Ch. Jenks, Yazyk arkhitektury postmodernisma (The language of Post-Modern architecture) (Moscow, Stroyizdat, 1985)

2. O.V. Maslovskaya, Formoobrazovanie i arkhitekturno-hudozhestvennaya interpretaciya vysotnoj zastrojki na primere gorodov SSHA, PhD Dissertation, 221 (Russia, Vladivostok, 2002)

3. O.V. Orelskaya, Sovremennaya zarubezhnaya arkhitektura: uchebnoe posobie dlya vuzov, 272 (Moscow, Akademiya, 2006)

4. G.I. Revzin, Ocherki po filosofii arkhitekturnoj formy (Moskva, OGI, 2002)-4

5. http://www.ctbuh.org/. (last accessed: 31st October 2016)

6. C. Willis, Form follows Finance: Skyscrapers and skylines in New York and Chicago, 221 (NY, Princeton Architectural Press, 1995)

7. M.A. Korotich, Kompozicionnoe razvitie vysotnoj arkhitektury. Akademicheskij vestnik URALNIIPROEKT, (Ekaterinburg, 2010)

8. M.A. Korotich, Kompozicionnye osobennosti strukturnogo formoobrazovaniya obolochek vysotnyh zdanij, Akademicheskij vestnik UralNIIproekt RAASN, 2, (2009)

9. V.P. Generalov, Osobennosti proektirovaniya vysotnyh zdanij (Samara, Samarskij gosudarstvennij arkhitekturno-stroitelnij universitet 2009)

10. Yu.K. Egorov-Tismenko, Kristallographiya I kristallohimiya, 592 (Moskva, KDU 2005)

11. Sila diagonalej, Zhurnal «ARX.» 1, 34-40 (2006)

12. http://naukovedenie.ru/PDF/32TVN515.pdf. (last accessed 21st April 2016)

13. Dmitrieva, Sovremennoye vysotnoe stroitel'stvo: ehffektivnye tekhnologii I materialy, Tekhnologii stroitelstva, 7, 4-10 (2005)

14. Yu.G. Granik, A. A. Magay Arkhitekturno-konstruktivnye osobennosti vysotnyh zdanij za rubezhom. Nnform, Unikalnye I specialnye tekhnologii v stroitelstve $\mathbf{1}$ (Moscow, Arkhitekturno-stroitelnyj centr «Dom na Brestskoj» 2004)

15. Rukovodstvo po vysotnym zdaniyam tipologiya I dizajn, stroitelstvo I tekhnologiya Edited by S. V. Nikolaev, 228 (Moscow, OOO «Atlant-Stroy», 2006)

16. Yhttp R. F. Bajmuratov, S. Kh. Bajmuratova, Resursy krupnogo goroda. Problemy stroitelnogo kompleksa Rossii: materialy Mezhdunarodnoj nauchno-prakticheskoj konferencii pri XIII specializirovannoj vystavke «Arkhitektura. Stroitelstvo. Kommunalnoe hozyajstvo-2009», 162-165, Ufa

17. http://archyort.ru/article/view/1869. (last accessed 21st April 2016)

18. U.V. Rasuleva, R. F. Bajmuratov, I. N. Sabitov, K. A. Donguzov, Imploziya Schemaforma, 100 (Ufa, Neftegazovoe delo, 2012)

19. I.N. Sabitov, R. F. Bajmuratov Vliyanie transporta na sovremennoe zhilishchnoe stroitelstvo v g. Ufe. Problemy stroitelnogo kompleksa Rossii, materialy Mezhdunarodnoj nauchno-prakticheskoj konferencii pri XI specializirovannoj vystavke «Stroitelstvo. Kommunalnoe hozyajstvo-2007», 232 (Ufa, 2007)

20. N. Sabitov, Yu. V. Rasuleva, E. G. Mazina, Implozivnyi metod I pyatoe izmerenie v arkhitekture. Arkhitekturnoe intersprostranstvo XXI veka: opyt, problemy, perspektivy: materialy Mezhdunarodnoj nauchno-prakticheskoj konferencii, 404 (Sankt-Peterburg, SPGASU, 2013) 